\title{
Carbon cost of collective farming collapse in Russia
}

\author{
IRINA KURGANOVA*†, VALENTIN LOPES DE GERENYU*, JOHAN SIX $\$$ and \\ YAKOV KUZYAKOV†§ \\ *Institute of Physicochemical and Biological Problems in Soil Science, RAS, Institutskaya st., 2, Pushchino, Moscow region \\ 142290, Russia, †Department of Soil Science of Temperate Ecosystems, Georg-August University of Göttingen, Büsgenweg 2, \\ Göttingen 37077, Germany, †Department of Environmental Systems Science, ETH-Zurich, TAN F4, Tannenstrasse 1, Zürich \\ 8092, Switzerland, §Department of Agricultural Soil Science, Georg-August University of Göttingen, Büsgenweg 2, Göttingen \\ 37077, Germany
}

\begin{abstract}
The collapse of collective farming in Russia after 1990 and the subsequent economic crisis led to the abandonment of more than 45 million ha of arable lands (23\% of the agricultural area). This was the most widespread and abrupt land use change in the 20th century in the northern hemisphere. The withdrawal of land area from cultivation led to several benefits including carbon (C) sequestration. Here, we provide a geographically complete and spatially detailed analysis of $\mathrm{C}$ sequestered in these abandoned lands. The average $\mathrm{C}$ accumulation rate in the upper $20 \mathrm{~cm}$ of mineral soil was $0.96 \pm 0.08 \mathrm{Mg} \mathrm{C} \mathrm{ha}^{-1} \mathrm{yr}^{-1}$ for the first 20 years after abandonment and $0.19 \pm 0.10 \mathrm{Mg} \mathrm{C} \mathrm{ha}^{-1} \mathrm{yr}^{-1} \mathrm{dur}^{-}$ ing the next 30 years of postagrogenic evolution and natural vegetation establishment. The amount of $\mathrm{C}$ sequestered over the period 1990-2009 accounts to $42.6 \pm 3.8 \mathrm{Tg}$ C per year. This C sequestration rate is equivalent to ca. 10\% of the annual $\mathrm{C}$ sink in all Russian forests. Furthermore, it compensates all fire and postfire $\mathrm{CO}_{2}$ emissions in Russia and covers about $4 \%$ of the global $\mathrm{CO}_{2}$ release due to deforestation and other land use changes. Our assessment shows a significant mitigation of increasing atmospheric $\mathrm{CO}_{2}$ by prolonged $\mathrm{C}$ accumulation in Russian soils caused by collective farming collapse.
\end{abstract}

Keywords: land use change, meta-analysis, organic carbon stocks, Russian Federation, soil carbon sequestration

Received 12 March 2013 and accepted 6 August 2013

\section{Introduction}

Globally, soils contain more carbon (C) than living plant biomass and the atmosphere together (Batjes, 1996; Smith, 2004; IPCC, 2007). The enormous size of the global soil organic C stock, along with its long turnover time, makes soils the most important part of the terrestrial C cycle at regional and global scales (Steffen et al., 1998; Schlesinger, 1999). Hence, any land use change (LUC) can significantly impact soil C stocks (Lal \& Kimble, 1997; Smith, 2004; Morris et al., 2007), ecosystem stability (Foley et al., 2005; Lepers et al., 2005; Macías \& Arbestain, 2010), carbon dioxide $\left(\mathrm{CO}_{2}\right)$ release into the atmosphere, and consequently global warming (Houghton, 2003; Lal, 2004; Ramankutty et al., 2006). Most agricultural activities, especially intensive tillage, lead to a decrease in soil organic $\mathrm{C}$ stocks and release $\mathrm{CO}_{2}$ into the atmosphere (Six et al., 1998; Guo \& Gifford, 2002; Smith et al., 2005, 2007). The reverse process - conversion of agricultural lands to natural vegetation - contributes significantly to $C$ reaccumulation in soils and is a significant action for medium- and longterm C sequestration (Post \& Kwon, 2000; Baer et al., 2010; Laganière et al., 2010). It has been estimated that

Correspondence: Irina Kurganova, tel. 007-4967-736845, Fax: 007-4967-330595, e-mail: ikurg@mail.ru cropland soils have a global potential to sequester $\mathrm{C}$ between 0.4 and $0.9 \mathrm{Pg} \mathrm{C}$ per year $\left(1 \mathrm{Pg}=10^{15} \mathrm{~g}\right.$ ) barely at the costs of improved agricultural management, restoration of degraded lands, extensive use of abandoned lands, and restoration of wetlands (Paustian et al., 1998, 2000; Lal, 2004). Simulation approach showed that the conversion of conventional tillage to no-till (57\% and $76 \%$ of field cropland planted) in USA could result in $C$ stock gain by the year 2020 at rate of 80-129 or 286-468 Tg C, respectively (Kern \& Johnson, 1993). It has been estimated that agricultural management and land use change in Europe resulted in a net sink for $\mathrm{CO}_{2}$ (Freibauer et al., 2004; Schulze et al., 2010). However, there is lack of large scale estimation of $\mathrm{C}$ stock changes in response to rapid and spontaneous croplands withdrawal.

Russia covers $11.5 \%$ of the world's land area and contains about $20 \%$ of all soil organic C stocks across the globe (Rojkov et al., 1996; Orlov, 1998; Stolbovoy, 2002). Hence, it plays a crucial role in the global C cycle (Nilsson et al., 2000; Kurganova et al., 2010; Kurganova \& Kudeyarov, 2012). After the collapse of the Soviet collective farming system in the early 1990s and the subsequent economic crisis, farmland area in the Russian Federation decreased drastically (Ioffe \& Nefedova, 2004). Namely, 45.5 million ha of 
arable lands were abandoned between 1990 and 2007 (Lyuri et al., 2010). This area remained nearly constant until 2011 due to the negligible changes in cultivation area (coefficient of variation $=1.3 \%$ for 2005-2011; Russia in figures, 2012). This cropland abandonment was the most widespread and abrupt LUC in the 20th century in the northern hemisphere and substantially shifted the total $\mathrm{C}$ balance on the Russian territory (Armstrong, 2008; Henebry, 2009). The cropland withdrawal was generally spontaneous, and the share of abandoned land in the total agricultural area in 1990 varied from 8.7 to $44.1 \%$ between Federal districts and averaged at about $23 \%$ for the whole territory (Table 1). More than $70 \%$ of the total abandoned area is now located in the European part of Russia.

Despite this great conversion of arable land, detailed assessments of the resulting changes in soil $\mathrm{C}$ stocks have not been conducted. Here, we provide a new analysis of $C$ sequestered in abandoned lands of Russia by considering the distribution, properties and specifics of $C$ sequestration in soils of various bioclimatic zones. This empirical soil-based approach is different from preceding estimates because previous approaches were based either on extrapolation of very few experiments (Larionova et al., 2003) or on simulations of $\mathrm{C}$ dynamics during postagrogenic evolution without experimental data obtained under field conditions in various bioclimatic zones (Romanovskaya, 2008; Vuichard et al., 2008). For our estimates, we first clustered soil types into five large soil groups (Albeluvisols, Luvisols, Chernozems, Kastanozems, and 'other soils') considered their $C$ sequestration rates in various bioclimatic zones and assessed their typical rates of $\mathrm{C}$ stock change depending on the period after LUC. This soil specific approach is based on $C$ accumulation rates in various soils and has not been used in previous analyses (Post \& Kwon, 2000; Guo \& Gifford, 2002; West \& Post, 2002; Laganière et al., 2010; Poeplau et al., 2011; Poeplau \& Don, 2013). Second, we calculated the total $C$ stocks sequestered in former arable lands through the period between 1990 and 2011 using soil-GIS and general approximation approaches.

\section{Materials and methods}

\section{Data collection}

All available studies conducted in the Russian Federation related to soil $\mathrm{C}$ stock changes after conversion of arable land to natural vegetation (grassland or forest) were collected.

Table 1 Area of total agricultural and abandoned farmland in Russia and annual changes in soil carbon stocks*

\begin{tabular}{|c|c|c|c|c|c|c|}
\hline \multirow[b]{2}{*}{ Federal district } & \multirow{2}{*}{$\begin{array}{l}\text { Agricultural } \\
\text { lands in } 1990 \\
\text { (million ha) }\end{array}$} & \multicolumn{2}{|c|}{$\begin{array}{l}\text { Abandoned lands (million } \\
\text { ha) }\end{array}$} & \multicolumn{2}{|c|}{$\begin{array}{l}\text { Share of young abandoned } \\
\text { lands }(\%) \text { in total }\end{array}$} & \multirow[b]{2}{*}{ 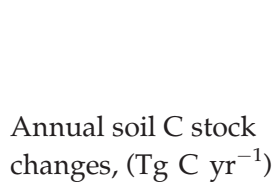 } \\
\hline & & $\begin{array}{l}\text { Total, incl. } \\
\text { young }\end{array}$ & $\begin{array}{l}\text { Young } \\
<18-20 \text { years }\end{array}$ & $\begin{array}{l}\text { Agricultural } \\
\text { area in } 1990\end{array}$ & $\begin{array}{l}\text { Abandoned } \\
\text { area }\end{array}$ & \\
\hline North European part & 73.6 & 34.8 & 18.5 & 25.1 & 53.2 & 14.1 \\
\hline North-Western & 5.7 & 6.4 & 2.2 & 38.6 & 34.4 & 1.2 \\
\hline Central & 20.3 & 12.6 & 7.5 & 36.9 & 59.5 & 5.2 \\
\hline Volga-Vyatka & 13.4 & 3.8 & 2.9 & 19.4 & 76.3 & 2.0 \\
\hline Ural & 34.2 & 12.0 & 5.9 & 17.2 & 49.2 & 5.6 \\
\hline South European part & 74.0 & 16.2 & 14.1 & 19.1 & 87.0 & 15.5 \\
\hline Central-Chernozem & 9.9 & 3.5 & 2.7 & 27.3 & 77.1 & 3.0 \\
\hline Volga & 40.0 & 10.5 & 9.3 & 23.3 & 88.6 & 10.1 \\
\hline North-Caucasian & 24.1 & 2.2 & 2.1 & 8.7 & 95.5 & 2.3 \\
\hline Asian part & 52.8 & 13.6 & 12.9 & 24.4 & 94.9 & 13.1 \\
\hline Western Siberia & 30.8 & 5.8 & 5.4 & 17.5 & 93.1 & 5.7 \\
\hline Eastern Siberia & 17.7 & 5.8 & 5.6 & 31.6 & 96.6 & 5.6 \\
\hline Far East & 4.3 & 2.0 & 1.9 & 44.1 & 95.0 & 1.9 \\
\hline Total & 200.4 & 64.6 & 45.5 & 22.7 & 69.7 & 42.6 \\
\hline
\end{tabular}

*The area shows the total agricultural and abandoned farmland (million of hectares) in the 10 main regions of the Russian Federation (summarized from 72 Federal districts) that were clustered into three large parts: north European, south European, and Asian. The percentage of land withdrawn after 1990 (young abandoned land) in the total agricultural and abandoned farmland was

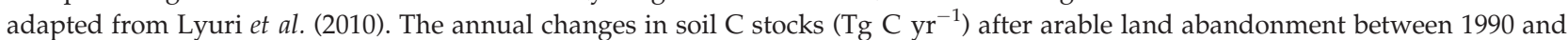
2009 are the results of the soil GIS approach application (averaged across the two assumptions: (i) the equal proportions; and (ii) the differential proportions [see Materials and Methods]). 
To be included in the database, the studies needed to have reported the following data: $\mathrm{C}$ stock (mass of $\mathrm{C}$ per unit area and depth) or $\mathrm{C}$ content (mass units) together with bulk density (BD) in paired plots (cropped and abandoned), or chronosequences with a clearly defined period after LUC, or under retrospective study meaning that the soil samples were collected periodically from the same plots during postagrogenic succession (Table S1). All chronosequences and retrospective studies usually consisted of more than two pair plots (current and former arable).

To estimate soil C stock from studies that reported the $\mathrm{C}$ content only, we used the average values of BD for arable and abandoned soils of the same soil type and identical texture. In total, 45 sites across Russian Federation and 116 pair plots were included in database for meta-analysis (Table S1). For correct comparison of all selected sites, we focused on the $\mathrm{C}$ stock changes in the upper $20 \mathrm{~cm}$ only, because the most common tillage depth was generally $20-22 \mathrm{~cm}$ and most studies indicated the greatest $C$ stock changes within this depth (Kalinina et al., 2011; Poeplau et al., 2011). Carbon accumulation in forest floor (O horizon) was not considered in this study because of its short turnover time.

\section{Data analysis}

The average annual rate of $\mathrm{C}$ stock changes was estimated for the main soil groups and data were then summarized according to periods after LUC: less than 20 years and between 21 and 50 years. Initially, we clustered all reported soil types into four main soil groups: Albeluvisols, Luvisols, Chernozems, and Kastanozems, which are the most representative soil groups in taiga, deciduous forest, forest- and central-steppe, and southern-steppe regions, respectively (Fridland, 1988; Targulyan \& Gerasimova 2007). These four main soil groups occupied about $85 \%$ of the total agricultural area in Russia before 1990 (Nilsson et al., 2000). All remaining soils (Umbrisols, Cambisols, Podzols, Fluvisols, Gleysoils, Planosols, Regosols, Arenosols, Solonetzes) that could not be associated with the four soil groups because of their specific properties formed the fifth group termed 'other soils'. They occupied $15 \%$ of agricultural lands.

The annual average rate of $C$ stock changes $(\Delta C$, $\mathrm{Mg} \mathrm{C} \mathrm{ha}{ }^{-1} \mathrm{yr}^{-1}$ ) over a time period $(T)$ was calculated as:

$$
\Delta C=\left(C_{a b}-C_{a r}\right) / T
$$

where $C_{a b}$ and $C_{a r}$ are $C$ stocks $\left(\mathrm{Mg} \mathrm{C} \mathrm{ha}^{-1}\right)$ in the upper $20 \mathrm{~cm}$ in abandoned and arable plots, respectively; $T$ (years) is the time period after LUC.

The simple mean and standard deviation (SD) for $\Delta \mathrm{C}$ values were calculated separately: (i) for two periods (less than 20 years after LUC and 21-50 years after LUC); and (ii) for main five soil groups in the first period (0-20 years after abandonment). Then the $\Delta \mathrm{C}$ values for each soil group exceeding \pm 1 SD were eliminated as outliers to normalize the distribution and to decrease the uncertainties of $\mathrm{C}$ accumulation rate in individual studies. The standard analysis of variance was carried out for main soil groups of $\Delta \mathrm{C}$ values at significance level of 0.05 (Devore \& Peck, 2001).
Due to the lack of sufficient number of experimental data it was impossible to estimate the rate of $\mathrm{C}$ accumulation during the second period of postagrogenic evolution (21-50 years after LUC) separately for each soil group. The average rate of $C$ stocks changes for this period $\left(\Delta C_{21-50}\right)$ was estimated with the following simple equation:

$$
\Delta C_{21-50}=\left(\Delta C_{2} \cdot 50-C_{1} \cdot 20\right) / 30
$$

where $\Delta C_{2}$ and $\Delta C_{1}$ are the means for the rate of $C$ stocks changes ( $\mathrm{Mg} \mathrm{C} \mathrm{ha}{ }^{-1} \mathrm{yr}^{-1}$ ) in the first (less than 20 years after LUC) and second (21-50 years after LUC) age categories respectively.

\section{Approaches for assessing of total $C$ sequestration in Russian soils after LUC}

The obtained average $\mathrm{C}$ accumulation rate in the five main soil groups for the first 20 years after LUC was used to calculate the total $\mathrm{C}$ sequestration in the whole Russian territory between 1990 and 2009 by two approaches. The first one - general approximation - is based on a general mean $\mathrm{C}$ accumulation rate for all soils during the first 20-year period after abandonment and the total farmland withdrawn between 1990 and 2009 (45.5 million ha).

The second - soil-GIS - approach considers the distribution of main soil groups within abandoned land in all 72 administrative-geographical regions of Russia. It included an overlaying of several GIS maps: (i) the Political Administrative Map of the USSR, $1: 8000$ 000, 1988 (Mikhailenko \& Bobkov, 1988); (ii) the Soil Map of the Russian Federation, 1 : 2500 000, 1988 (Fridland, 1988); and (iii) the Map of Land Categories in the USSR, 1 : 4000 000, 1989 (Yanvareva, 1989). These maps were used to calculate the farmland areas for each of the five main soil groups (Albeluvisols, Luvisols, Chernozems, Kastanozems, and 'other soils') in each of the Russian administrative regions existing before 1990 .

For all 72 administrative-geographical regions of Russia, we determined the distribution of former farmlands abandoned between 1990 and 2009 (i.e. $45.5 \mathrm{~m}$ ha in total; Lyuri et al., 2010) across the main soil types by using two assumptions: (i) the equal proportions (EP) assumption considered that the soils were abandoned irrespective of their types and consequently irrespective of their fertility; whereas (ii) the differential proportions (DP) assumption considered the less fertile soils to be first abandoned. For instance, because Chernozems are the highest fertile soils, they were abandoned after Luvisols (in Northern and Central regions) and after Kastanozems in Southern regions. Albeluvisols were withdrawn before Luvisols and the group 'other soils' since they are usually less fertile soils.

According to the recent study of Prishchepov et al. (2013), a higher likelihood of farmland abandonment was associated with lower average grain yields in the late 1980s (because of low soil fertility) and with higher distances from the nearest settlements or municipality centers (spontaneous human factor). Therefore, the true distribution of abandoned soils lies likely between the 'equal proportions' and 'differential proportions' assumptions. 


\section{Estimation of uncertainties and sensitivity analysis}

The overall uncertainty around the estimate of total soil C sequestration in the Russian territory is mainly affected by the precision of experimental data on $\mathrm{C}$ accumulation rate, because the area of abandoned cropland is nearly constant for 2007-2011 (45.5 M ha). Therefore, the uncertainty of estimation for total $C$ sequestration was estimated by one standard deviation ( $1 \sigma$ ) for $C$ accumulation rate (general population for the first period category) considering the total area of abandoned land (GA assumption) or by weighted root-mean-square standard deviation for subgroup samples (DP assumption; Dmitriev, 2009).

Sensitivity analysis to changes in $\mathrm{C}$ accumulation rates in five main soil groups was performed to estimate the response of total $\mathrm{C}$ sequestration in abandoned soils of the Russian Federation. The $\mathrm{C}$ accumulation rates in five main soil groups were varied for $\pm 25 \%$ of the experimentally estimated values, and the response of total $\mathrm{C}$ accumulation was analyzed. We assumed that the total area and distribution of abandoned land according to soil groups were constant during observation period.

\section{Results}

\section{Changes in $C$ stocks after arable lands abandonment}

The annual rate of soil organic carbon changes $(\Delta C)$ in mineral topsoil for individual plots varied widely: from -0.23 to $3.70 \mathrm{Mg} \mathrm{C} \mathrm{ha}^{-1} \mathrm{yr}^{-1}$ and were strongly depended on soil type, period after LUC, and initial C content in the arable soil before abandonment. The average $C$ accumulation rate was $0.96 \pm 0.08$ $\mathrm{Mg} \mathrm{C} \mathrm{ha}{ }^{-1} \mathrm{yr}^{-1}$ in the upper $20 \mathrm{~cm}$ of mineral soils for

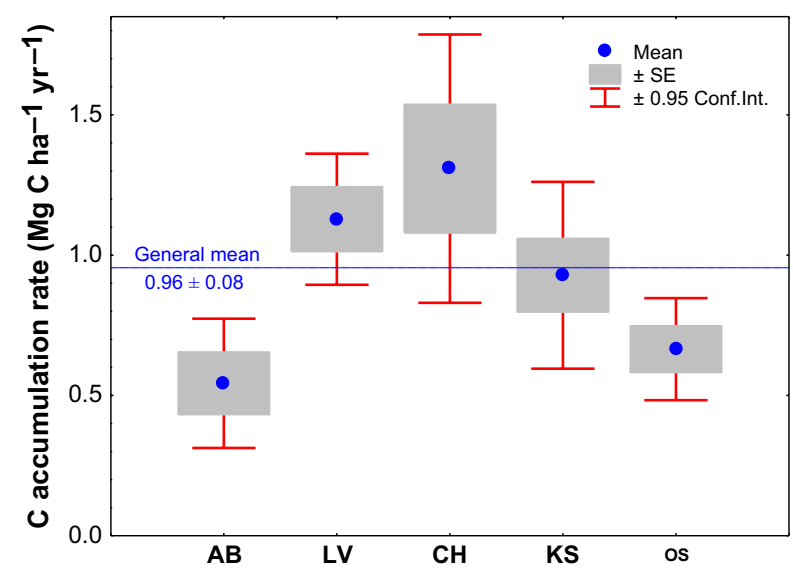

Fig. 1 Average $C$ accumulation rates $( \pm S E)$ in five main soil groups for the first 20 years after abandonment of cultivation (1990-2009). The confidence interval reflects significant differences $(P<0.05)$ between the soil groups. The five main soil groups according to Targulyan \& Gerasimova (2007) are: AB, Albeluvisols; LV, Luvisols; CH, Chernozems; KS, Kastanozems; os, 'other soils'. the first 20 years of postagrogenic evolution (Fig. 1). The $\mathrm{C}$ accumulation rate, however, significantly differed between main soil groups (Fig. 1): it was the highest in Chernozems $\left(1.31 \pm 0.23 \mathrm{Mg} \mathrm{C} \mathrm{ha}{ }^{-1} \mathrm{yr}^{-1}\right)$ and the lowest in Albeluvisols $(0.55 \pm 0.11 \mathrm{MgC}$ $\left.\mathrm{ha}^{-1} \mathrm{yr}^{-1}\right)$. The distribution of $\mathrm{C}$ accumulation rates in the soil groups generally corresponds to their $\mathrm{C}$ stocks under natural vegetation: the highest in Chernozems and the lowest in Albeluvisols.

The lowest variation of $\mathrm{C}$ accumulation rates was observed for the group 'other soils', despite various soils were joined in this category. Consequently, the assemblage of remaining various soils to one group is acceptable and it does not increase the uncertainty of estimated $C$ sequestration.

Based on our database, we also calculated that the $\mathrm{C}$ accumulation rate in soils of Russia will decrease strongly over the next 30 years of postagrogenic evolution and is estimated to be equal to $0.19 \pm 0.10$ $\mathrm{MgCha} \mathrm{yr}^{-1}$.

\section{Distribution of abandoned lands on Russian territory according to main soil types}

According to FAO statistics (http://faostat.fao.org/ site/418/default.aspx) and considering the area of real croplands and fictitious fallows, Lyuri et al. (2010) estimated the total area withdrawn from agriculture between 1990 and 2007 of 48.0 million ha including 45.5 million ha of former arable lands. The contribution of the five main soil groups to the Russian land cover depends mainly on climatic and bio-geographic conditions, while the share of cropland abandonment strongly depends on economic structure of regions in each Federal district (Prishchepov et al., 2012). Therefore, the contributions of the main soil groups to the abandoned area in various Federal districts varied substantially. Applying the soil-GIS approach and using two assumptions (i.e. EP vs. DP of abandonment across fertile vs. nonfertile soils), we estimated the distribution of the five main soil groups to the abandoned lands in all 72 administrative regions and summarized the results for 10 Federal districts (Table 2). Furthermore, these districts were clustered in three large agricultural parts of Russia: (i) northern European region; (ii) southern European region; and (iii) Asian region.

According to equal proportions assumption, Albeluvisols were the prevailing soils in the northern part of European Russia and contributed about 50\% to the total area of abandoned lands in this region. In the southern part of European Russia, the highest part $(\approx 59 \%)$ of lands abandoned through the last 20 years occurs on Chernozems, while the 'other soils' cover about $50 \%$ of withdrawal area in the Asian part. The differential 
approach demonstrated, however, the diverse distribution of abandoned lands on Russian territory. Thus, Albeluvisols contributed $75 \%$ of total abandoned area in North Eurasian part. Kastanozems, 'other soils', and Luvisols cover respectively about 32,30 , and $22 \%$ of withdrawal area in Southern European part, while the 'other soil' category comprised the largest share (ca. 70\%) of abandoned land in Asian Russia (Table 2).

Averaging the results obtained, we could conclude that in northern European Russia, the dominating Albeluvisols group occupied more than $60 \%$ of the total abandoned area, whereas in the southern European Russia, Chernozems and Kastanozems contributed 34\% and $25 \%$, respectively (Fig. 2). In the Asian part, the 'others soils' group comprised the largest share of abandoned land $(62 \%)$.

\section{Carbon sequestration in the main Federal districts of Russian Federation for 1990-2009}

The total C sequestration for Russian territory (soil GIS approach application) varied between 38.9 and $46.4 \mathrm{Tg} \mathrm{C}$ per year (Table 2) and averaged across the two assumptions $42.6 \pm 3.8 \mathrm{Tg} C$ per year over the period 1990-2009. The greatest total C sequestration (10.1 $\mathrm{Tg} \mathrm{C} \mathrm{yr}^{-1}$, corresponding to $23.7 \%$ of total sequestered C) was observed in the Volga district, which contributed $20 \%$ of the total abandoned area

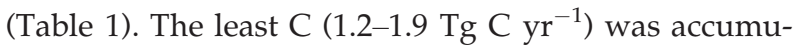
lated in the North-Western and Far East regions, which did not exceed $5 \%$ of total $\mathrm{C}$ accumulation due to LUC after 1990. The northern and southern European parts contributed similarly to the total $\mathrm{C}$ sequestered in soils

Table 2 The area of lands abandoned after 1990 according to main soil units and total annual soil carbon stock changes for 19902009 in main Federal districts of Russian Federation (estimated by two approaches)

\begin{tabular}{|c|c|c|c|c|c|c|c|}
\hline \multirow[b]{2}{*}{ Federal district } & \multicolumn{6}{|c|}{ Area of lands abandoned (million ha) } & \multirow{2}{*}{ 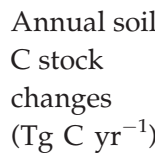 } \\
\hline & $\begin{array}{l}\text { Albelu-visols, } \\
\mathrm{AB}\end{array}$ & $\begin{array}{l}\text { Luvi-sols, } \\
\text { LV }\end{array}$ & $\begin{array}{l}\text { Cherno-zems, } \\
\mathrm{CH}\end{array}$ & Kastanozems, KS & $\begin{array}{l}\text { Other soils, } \\
\text { os }\end{array}$ & Total & \\
\hline \multicolumn{8}{|c|}{ Equal proportions approach } \\
\hline North European part & 9.23 & 2.62 & 4.12 & 0.11 & 2.46 & 18.54 & 15.7 \\
\hline North-Western & 1.60 & 0.00 & 0.00 & 0.00 & 0.58 & 2.18 & 1.3 \\
\hline Central & 4.98 & 0.97 & 0.75 & 0.00 & 0.83 & 7.51 & 5.6 \\
\hline Volga-Vyatka & 1.45 & 0.80 & 0.31 & 0.00 & 0.36 & 2.93 & 2.5 \\
\hline Ural & 1.20 & 0.85 & 3.06 & 0.11 & 0.69 & 5.92 & 6.4 \\
\hline South European part & 0.28 & 1.52 & 8.38 & 2.49 & 1.41 & 14.08 & 16.5 \\
\hline Central-Chernozem & 0.07 & 0.25 & 2.13 & 0.00 & 0.25 & 2.70 & 3.4 \\
\hline Volga & 0.21 & 1.25 & 4.87 & 2.02 & 0.94 & 9.29 & 10.7 \\
\hline North-Caucasian & 0.00 & 0.02 & 1.38 & 0.47 & 0.22 & 2.09 & 2.5 \\
\hline Asian part & 0.61 & 0.18 & 4.24 & 0.9 & 6.96 & 12.89 & 14.2 \\
\hline Western Siberia & 0.09 & 0.18 & 3.71 & 0.90 & 0.54 & 5.41 & 6.5 \\
\hline Eastern Siberia & 0.08 & 0.00 & 0.00 & 0.00 & 5.46 & 5.54 & 5.8 \\
\hline Far East & 0.44 & 0.00 & 0.53 & 0.00 & 0.96 & 1.94 & 1.9 \\
\hline Grand total & 10.12 & 4.32 & 16.74 & 3.50 & 10.83 & 45.51 & 46.4 \\
\hline \multicolumn{8}{|l|}{ Differential approach } \\
\hline North European part & 13.47 & 1.18 & 0.13 & 0.00 & 3.76 & 18.54 & 12.5 \\
\hline North-Western & 2.18 & 0.00 & 0.00 & 0.00 & 0.00 & 2.18 & 1.2 \\
\hline Central & 6.20 & 1.18 & 0.13 & 0.00 & 0.00 & 7.51 & 4.9 \\
\hline Volga-Vyatka & 2.93 & 0.00 & 0.00 & 0.00 & 0.00 & 2.93 & 1.6 \\
\hline Ural & 2.16 & 0.00 & 0.00 & 0.00 & 3.76 & 5.92 & 4.8 \\
\hline South European part & 1.06 & 3.06 & 1.30 & 4.44 & 4.22 & 14.08 & 14.4 \\
\hline Central-Chernozem & 0.36 & 1.26 & 0.21 & 0.00 & 0.88 & 2.70 & 2.7 \\
\hline Volga & 0.70 & 1.64 & 0.85 & 4.15 & 1.94 & 9.29 & 9.6 \\
\hline North-Caucasian & 0.00 & 0.16 & 0.24 & 0.29 & 1.4 & 2.09 & 2.1 \\
\hline Asian part & 1.32 & 0.58 & 1.85 & 0.18 & 8.96 & 12.89 & 12.0 \\
\hline Western Siberia & 0.85 & 0.00 & 0.00 & 0.00 & 4.56 & 5.41 & 4.8 \\
\hline Eastern Siberia & 0.08 & 0.58 & 1.32 & 0.18 & 3.38 & 5.54 & 5.3 \\
\hline Far East & 0.39 & 0.00 & 0.53 & 0.00 & 1.02 & 1.94 & 1.8 \\
\hline Grand total & 15.85 & 4.82 & 3.28 & 4.62 & 16.94 & 45.51 & 38.9 \\
\hline
\end{tabular}




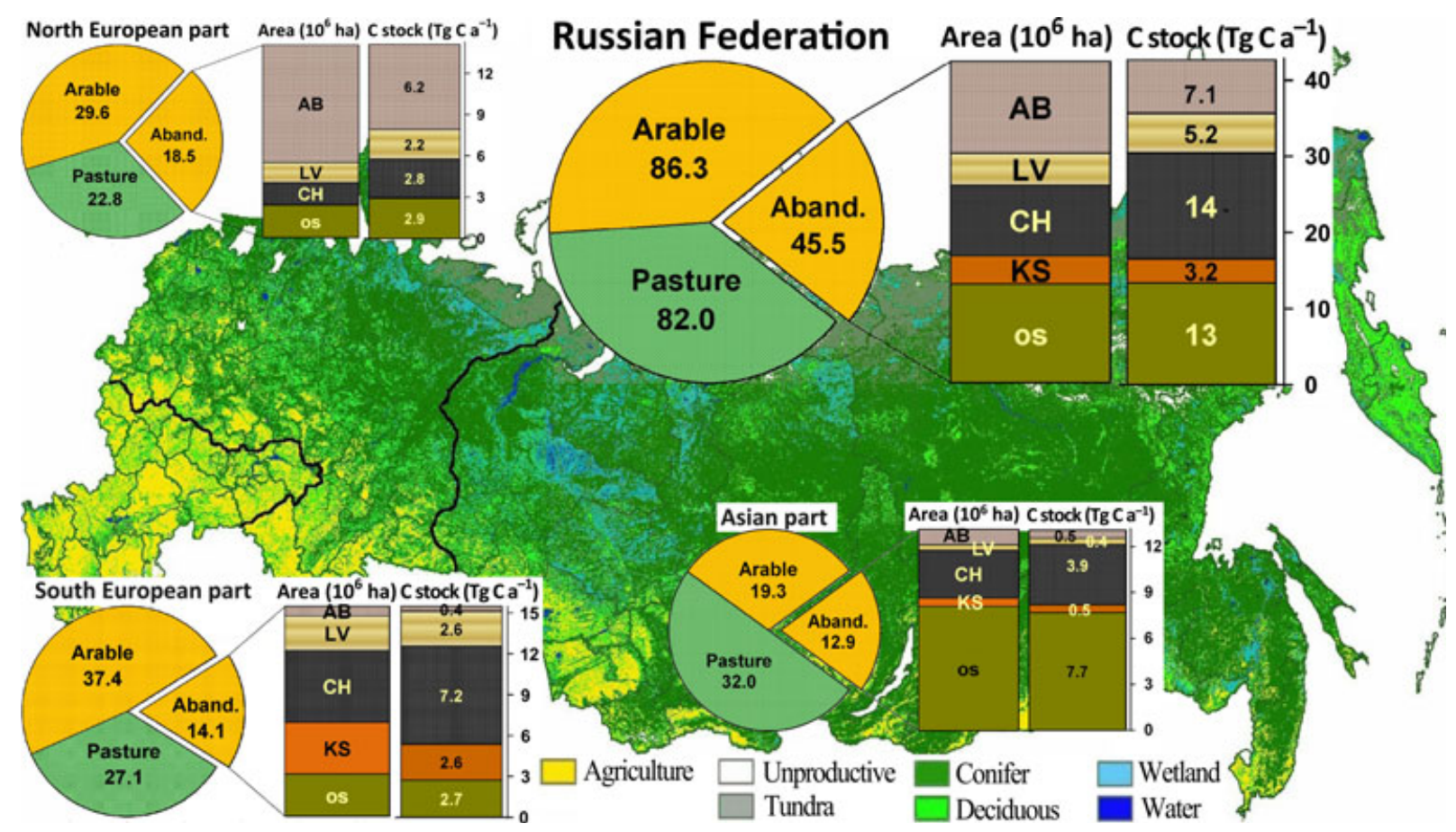

Fig. 2 The distribution of main soil groups and their contributions to total C sequestration within the lands abandoned between 1990 and 2009 in northern and southern European parts, and Asian part of Russia. Total area of agricultural land corresponds to 1990. The estimation of $C$ sequestration is the average value between assumed equal proportions and differential soil abandonment. The five main soil groups are: AB, Albeluvisols; LV, Luvisols; CH, Chernozems; KS, Kastanozems; os, 'other soils'.

due to LUC after 1990. Both European parts together sequestered 29.6 $\mathrm{Tg} \mathrm{C} \mathrm{yr}^{-1}$, which was about 2.3 times more than in the Asian part (Table 1), which contributed about $30 \%$ to total agricultural area of Russian Federation (Fig. 2).

The general approximation approach and the soilGIS one showed that the collapse of collective farming system induced a substantial $\mathrm{C}$ sequestration in soils that amounted for $0.92-0.96 \mathrm{Mg} \mathrm{C}^{-1} \mathrm{yr}^{-1}$ during the first 20 years after LUC (Table 3). Despite the fact that both obtained estimates of total soil $\mathrm{C}$ stocks were very close and depended minimally on calculation approach, our results clearly demonstrated the advantages of the soil-GIS approach since its uncertainty was 3.3 times lower than of the 'general approximation' (Table 3). This is the result of higher precision of $C$ stock changes (i.e. lower SD values) within the five main soil groups used for the GIS-approach in comparison with the high uncertainty of the general mean for $\mathrm{C}$ accumulation rate that was the basis for general approximation approach.

Sensitivity analysis of the response of total $C$ sequestration to the changes of $C$ sequestration rates showed high stability of the estimated total $\mathrm{C}$ sequestration in abandoned soils of Russian Federation (Fig. 3). Chernozems and 'other soils' groups had the highest impact on C sequestration assessment. However, even this impact was of minor importance: when the changes in $\mathrm{C}$ accumulation rate in these soils amounted to $20-25 \%$, the total $\mathrm{C}$ sequestration altered only by $6-7 \%$. The same changes in $\mathrm{C}$ stocks after LUC for other soils (Albeluvisols, Luvisols, and Kastanozems) led to very minor changes $(2-4 \%)$ in total $\mathrm{C}$ sequestration.

\section{Discussion}

Changes in soil carbon stock during postagrogenic evolution

The former arable soils can both accumulate and lose C during postagrogenic evolution and succession of natural vegetation. The direction and intensity of changes depend mainly on the fertility status of the control arable plots and bioclimatic region. The decrease of $\mathrm{C}$ stocks (negative $\Delta C$ ) during the first few years after abandonment was common only for arable soils with a high initial level of organic $\mathrm{C}$ and took place mainly in northern districts (Albeluvisols). The slight initial losses of $C$ were also observed in other studies during natural spruce forests establishment in southern taiga zone of European Russia (Kalinina et al., 2009, 2010; Lyuri et al., 2010) as well as in other cool temperate zones under 
Table 3 Estimations of total carbon sequestration in former arable lands of Russia

\begin{tabular}{llllll}
\hline Period & Area (M ha) & Approach & $\begin{array}{l}\text { Total C sequestration } \\
(\mathrm{Tg} \mathrm{C})\end{array}$ & $\begin{array}{l}\text { Average rate of C sequestration } \\
\left(\mathrm{Mg} \mathrm{C} \mathrm{ha}^{-1} \mathrm{yr}^{-1}\right)\end{array}$ & Reference \\
\hline $1990-2011$ & $45.5^{*}$ & Soil-GIS & $870(254)^{*}$ & $0.92(0.28)$ & Present study \\
$1990-2011$ & $45.5^{*}$ & Approximation & $861(646)^{*}$ & $0.96(0.72)$ & Present study \\
$1990-2006$ & 30.2 & Soil GIS & $648(47)$ & $1.26(0.09)$ & Kurganova et al., 2010; \\
$1990-2006$ & 30.2 & Approximation & $585(33)$ & $1.14(0.06)$ & Kurganova et al., 2010; \\
$1990-2005$ & 27.9 & RothC model & $248(37)$ & $0.55(0.08)$ & Romanovskaya, 2008; \\
$1991-2000$ & 20.0 & Orchidee model & 64 & 0.47 & Vuichard et al., 2008; $*$ Larionova et al., 2003 \\
$1990-2004$ & 34.0 & Approximation & 660 & 1.29 & Larion \\
\hline
\end{tabular}

The estimations are based on different approaches and were done for various periods and areas of abandoned arable lands due to LUC after 1990. The one-sigma uncertainties of total C sequestration and average C sequestration rate estimated in the present study are shown in parentheses. The two studies at the bottom did not provide any uncertainty of the estimations.

*The rates of $\mathrm{C}$ sequestration and areas of abandoned lands were used for calculation of total $\mathrm{C}$ accumulation during the first 20 years after LUC (1990-2009). For the period 2010-2011 the total area of abandoned lands was $45.1 \mathrm{~m}$ ha and the average rate of C-sequestration was $0.19 \mathrm{Mg} \mathrm{C}^{-1} \mathrm{yr}^{-1}$.

**This estimation included the whole area of former USSR based on FAO statistics for 2000.

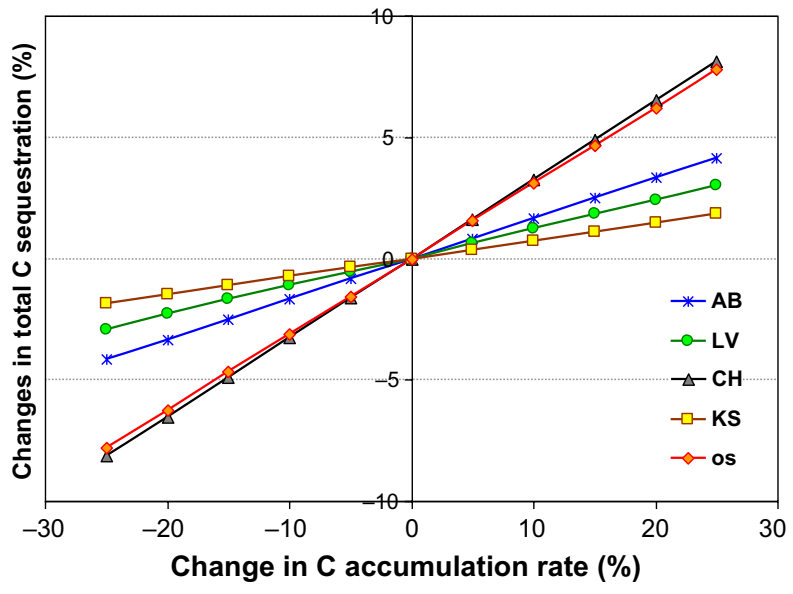

Fig. 3 Sensitivity analysis of the response of total C sequestration to the changes in carbon accumulation rates in five main soil groups of abandoned soils of Russian Federation. The response is presented as a percentage of the average $C$ sequestration (see Fig. 1). The sensitivity analysis was done for the GIS approach based on Equal proportions assumption and Differential assumption (see text); the average response between the two assumptions is presented.

pine dominated natural succession (Post \& Kwon, 2000) or under Scot pine and Silver birch plantations (Armolaitis et al., 2007; Karhu et al., 2011). However, due to the accumulation of litter in the organic horizon (forest floor, O horizon), the abovementioned studies observed a total increase in C stocks of the investigated soils (Podsols, Albeluvisol, Arenosols).

The highest $C$ accumulation rates were observed in former arable Chernozems that were used intensively in agriculture. Due to the deep and frequent tillage as well as strong decrease of above- and belowground litter input compared to natural steppe vegetation, the depletion of $\mathrm{C}$ stocks in Chernozems took place until
1990 (Khmelev, 1989). Around 30\% of initial C stocks were lost in the West-Siberian region from 1930 to 1990 (Titlyanova \& Naumov, 1995; Titlyanova et al., 1998). For the Chernozems of European Russia, the C losses comprised about $20-30 \%$ of the initial C stock (Mikhailova et al., 2000). Therefore, after withdrawal of arable Chernozems and establishment of natural vegetation, these soils have the highest potential for $\mathrm{C}$ accumulation. In addition, the $\mathrm{C}$ accumulated in Chernozems after land use change from arable to permanent grassland was mainly presented in the recalcitrant $\mathrm{C}$ pools (Lopes de Gerenyu et al., 2008).

Although the estimates of $\mathrm{C}$ accumulation rate in this study seem to be rather high, they are reasonable given that the arable lands abandoned after 1990 had a high C deficit due to the fourfold restriction of fertilizers application in early 1990s compared with 1980s (Russia in figures, 2011). Strong reduction of fertilizers application resulted in reduced crop productivity and hence $C$ inputs by roots, rhizodeposition and aboveground crop residues to the cultivated soils. Furthermore, the $\mathrm{C}$ sequestration rates estimated for Russian soils correspond well to those reported after conversion of croplands to forest or grassland $\left(0.44-0.92 \mathrm{Mg} \mathrm{C} \mathrm{ha}^{-1} \mathrm{yr}^{-1}\right.$ in the upper $25 \mathrm{~cm}$ of mineral soil) in a recent metaanalysis for temperate regions (Poeplau et al., 2011). In the tropics, however, the mean annual $\mathrm{C}$ accumulation due to arable land abandonment is higher: 1.30 Mg C ha $\mathrm{yr}^{-1}$ (Silver et al., 2000).

Total C sequestration in abandoned soils of Russia and its relevance

The previous estimations of $C$ sequestration in abandoned soils of Russia varied widely and depended on (i) calculation approach; (ii) area of considered 
abandoned arable lands; and (iii) sequestration period (Table 3). The first estimate (660 Tg C or 1.29 $\left.\mathrm{Mg} \mathrm{C} \mathrm{ha}{ }^{-1} \mathrm{yr}^{-1}\right)$, based on very limited experimental data (only three plots in Central Russia), was done for the period 1990-2002 and considered 34 million ha of abandoned land (Larionova et al., 2003). The estimation by the 'Orchidee' model (Vuichard et al., 2008) for the whole territory of the former USSR (64 Tg C or $0.47 \mathrm{Mg} \mathrm{C} \mathrm{ha}^{-1} \mathrm{yr}^{-1}$ ) strongly underestimated the $C$ accumulated between 1991 and 2000 in comparison to our estimates. This underestimation of long-term $\mathrm{C}$ accumulation in soils is probably due to both the very low area of land withdrawal considered and the fact that the Orchidee model was calibrated only by one chronosequence of postagrogenic ecosystems located in Siberia, while most abandoned arable lands are located in the European part of Russia, where a different climate and land history prevail. The RothC soil model approach (Romanovskaya, 2008) led to greater $C$ sequestration in the former cultivated lands in Russia (27.9 million ha), namely 248 Tg C during 1990-2005 or $0.55 \mathrm{Mg} \mathrm{C}^{-1} \mathrm{yr}^{-1}$. Compared with our study, the RothC approach also underestimated the C sequestration for the 1990-2005 period, probably because RothC was calibrated based on soil data from 1960-1970 period when soil fertility was greater due to higher fertilizer application rates. The soil GIS approach was applied to update total C stock in Russian soils for the first time in our previous study (Kurganova et al., 2010). The annual rates of $C$ stock changes in postagrogenic soils were estimated for the first 15 years after abandonment (19902005) and they were greater than the estimates for the same soil types presented here. Furthermore, in the present study, we used geographically complete and spatially detailed experimental data to improve the estimate of abandoned areas in the Russian Federation over a 20-year period.

With our comprehensive approach, we show that the abandoned soils in the Russian Federation provided an additional, previously underestimated, $\mathrm{C}$ sequestration at a rate of $42.6 \pm 3.8 \mathrm{Tg} \mathrm{C} \mathrm{yr}^{-1}$ in the upper $20 \mathrm{~cm}$ of mineral soils during the first 20 years after LUC. This corresponds to ca. 10-20\% of the annual C sink in all Russian forests (Ciais et al., 2010; Pan et al., 2011; Zamolodchikov et al., 2011), even though the forest area is about 25 times larger than the abandoned farmland. This extra $\mathrm{C}$ accumulated in former arable soils is a significant part of the Russian $\mathrm{C}$ balance and equals to about $10 \%$ of the current fossil fuel emissions of Russia (Canadell et al., 2007) or all fire and postfire $\mathrm{CO}_{2}$ emissions (Russia in figures, 2011). The calculated extra soil C stock comprises ca. 1/4-1/3 of the total European biosphere sink (Janssens et al., 2003); it is also equivalent to about $4 \%$ of global $\mathrm{CO}_{2}$ release due to deforestation and other land use disturbances (Canadell et al., 2007; Le Quéré et al., 2009).

The presented $C$ sequestration is a retrospective estimation. Based on the annual rates of $\mathrm{C}$ accumulation from 20 to 50 years after abandonment $\left(8.7 \mathrm{Tg} \mathrm{C} \mathrm{yr}^{-1}\right)$, future $C$ changes can also be predicted for the next 30 years. Assuming a constant area of abandoned land (ca. 45 million ha), the additional $\mathrm{C}$ sink for the 20-50 years after abandonment would be about $261 \mathrm{Tg} \mathrm{C}$. The total extra C sequestered over the 50 years $(1113 \mathrm{Tg} \mathrm{C}$ ) corresponds approximately to $10 \%$ of the total organic C stocks in the upper $20 \mathrm{~cm}$ of all agricultural soils of Russia until 1990 (ca. 11550 Tg C; Orlov, 1998). The real C costs of LUC on Russian territory after 1990 could be greater due to the significant $C$ accumulation deeper than $20 \mathrm{~cm}$ soil layer and in the forest litter, which were not considered here.

However, the $\mathrm{C}$ stock after LUC will not increase infinitely. After 60-120 years, it reach an equilibrium level (Silver et al., 2000; Poeplau et al., 2011), which depends on physicochemical and biological stabilization mechanisms (Six et al., 2002).

Concluding, the farming system collapse in Russia in early 1990s caused an abrupt and widespread land use change in northern hemisphere - more than 45 million ha of arable lands were abandoned after 1990. The succession of natural vegetation and recovery of soil during postagrogenic evolution resulted in a significant sequestration of $C$ in soils and a substantial shift in the Russian C budget. In contrast with previous estimations, we considered: (i) much more experimental sites (i.e. 116 pair plots); (ii) specifics of soil properties in various climatic zones; (iii) distribution of soil groups in federal districts; (iv) applied and compared various calculation approaches; (v) assessed the uncertainties of $C$ sequestration estimates; and (vi) conducted a sensitivity analysis of the effects of changes of $C$ sequestration rates on total $\mathrm{C}$ sequestration. The average $\mathrm{C}$ accumulation rate in the upper $20 \mathrm{~cm}$ of mineral soil was $0.96 \pm 0.08 \mathrm{Mg} \mathrm{C} \mathrm{ha}^{-1} \mathrm{yr}^{-1}$ for the first 20 years after abandonment and $0.19 \pm 0.10 \mathrm{Mg} \mathrm{C} \mathrm{ha}^{-1} \mathrm{yr}^{-1}$ during the next 30 years of postagrogenic evolution. This accounts to $42.6 \pm 3.8 \mathrm{Tg} \mathrm{C}$ per year that was sequestered over the period 1990-2009 and about 8.7 Tg C per year for 2010-2011. This extra C sequestered in Russian soils in the previous 20 years and expected in the next 30 years after collective farming system collapse (1990-2040) will able to provide about $10 \%$ increase of total organic C pool in Russian soils. Our assessment shows a significant mitigation of climate change effects because of the prolonged $\mathrm{C}$ accumulation in Russian soils caused by recent LUC. The sequestration of atmospheric $\mathrm{CO}_{2}$ in soil contributes 
considerably to Russia's attempts to adhere to the Kyoto protocol and future post-Kyoto climatic agreements. Therefore, the dissolution of the Soviet Union in the early 1990s, along with the subsequent collapse of the collective farming system, had not only global political repercussions, but also positive and prolonged ecological implications.

\section{Acknowledgments}

This study was supported by the Russian Foundation for Basic Research (RFBR) and German Academic Exchange Service (DAAD). It would not be possible without Russian researchers who measured and provided the data on $\mathrm{C}$ sequestration collected in the database. We thank Prof. A. Shvidenko for his considerable assistance in GIS-approach application. We are very thankful to anonymous reviewers for valuable comments and suggestions.

\section{References}

Armolaitis K, Aleinikoviend J, Baniunien A et al. (2007) Carbon sequestration and nitrogen status in Arenosols following afforestation or following abandonment of arable land. Baltic Forestry, 13, 169-178.

Armstrong A (2008) Carbon cycle: a return to Soviet soils. Nature Geosciences, 1, 810.

Baer SG, Meyer CK, Bach EM et al. (2010) Contrasting ecosystem recovery on two soil textures during grassland restoration: implications for conservation and mitigation. Ecosphere, 1, 1-22.

Batjes NH (1996) Total carbon and nitrogen in the soils of the world. European Journal of Soil Science, 47, 151-163.

Canadell JG, Le Quéréc C, Raupach MR et al. (2007) Contributions to accelerating atmospheric $\mathrm{CO}_{2}$ growth from economic activity, carbon intensity, and efficiency of natural sinks. Proceedings of the National Academy of Sciences of the United States of America, 104, 18866-18870.

Ciais P, Canadell JG, Luyssaert S et al. (2010) Can we reconcile atmospheric estimates of the Northern terrestrial carbon sink with land-based accounting? Current Opinion in Environmental Sustainability, 2, 225-230.

Devore J, Peck R (2001) Statistics: The Exploration and Analysis Data. 4th edn, Thomson Learning, Duxbury, USA

Dmitriev EA (2009) Mathematical Statistics in Soil Science. Librokom, Moscow [in Russian].

Foley JA, DeFries R, Asner GP et al. (2005) Global Consequences of Land Use. Science, 309, 570-574

Freibauer A, Rounsevell MDA, Smith P et al. (2004) Carbon sequestration in the agricultural soils of Europe. Geoderma, 122, 1-23.

Fridland VM (ed.) (1988) Soil map of the Russian Soviet Federative Socialist Republic at scale 1:2.5M. Central Administration for Geodesy and Cartography (GUGK), Moscow, Russia, 16 sheets [in Russian].

Guo LB, Gifford RM (2002) Soil carbon stock and land use change: a meta analysis. Global Change Biology, 8, 345-360.

Henebry GM (2009) Carbon in idle croplands. Nature, 457, 1089-1090.

Houghton RA (2003) Revised estimates of annual net flux of carbon to the atmosphere from changes in land use and land management 1850-2000. Tellus, 55B 378-390.

Ioffe G, Nefedova T (2004) Marginal farmland in European Russia. Eurasian Geography Economics, 45, 45-59.

IPCC (2007) Climate change 2007: synthesis report. In: Contribution of Working Groups I, II and III to the Fourth Assessment Report of the Intergovernmental Panel on Climate Change, (eds Pachauri RK, Reisinger A) IPCC, Geneva, Switzerland.

Janssens IA, Freibauer A, Ciais P et al. (2003) Europe's terrestrial biosphere absorbs 7-12\% of European anthropogenic $\mathrm{CO}_{2}$ emissions. Science, 300, 1538-1542.

Kalinina O, Goryachkin SV, Karavaeva NA et al. (2009) Self-restoration of post-agrogenic sandy soils in the southern Taiga of Russia: soil development, nutrient status, and carbon dynamics. Geoderma, 152, 35-42.

Kalinina O, Goryachkin SV, Karavaeva NA et al. (2010) Dynamics of carbon pools in post-agrogenic sandy soils of southern Taiga of Russia. Carbon Balance and
Management, 5, 1. Available at: http://www.cbmjournal.com/content/5/1/1 (accessed on 26 April 2010).

Kalinina O, Krause SE, Goryachkin SV et al. (2011) Self-restoration of post-agrogenic chernozems of Russia: soil development, carbon stocks, and dynamics of carbon pools. Geoderma, 162, 196-206.

Karhu K, Wall A, Vanhala P et al. (2011) Effects of afforestation and deforestation on boreal soil carbon stocks - comparison of measured C stocks with Yasso07 model results. Geoderma, 164, 33-45.

Kern JS, Johnson MG (1993) Conservation tillage impacts on national soil and atmospheric carbon levels. Soil Science Society of America, 57, 200-210.

Khmelev VA (1989) Loessial Chernozems of Western Siberia. Nauka, Siberian Branch, Novosibirsk.

Kurganova IN, Kudeyarov VN (2012) Ecosystems of Russia and global carbon budget. Science in Russia, 5, 25-32

Kurganova IN, Kudeyarov VN, Lopes de Gerenyu VO (2010) Updated estimate of carbon balance on Russian territory. Tellus, 62B, 497-505.

Laganière J, Angers DA, Paré D (2010) Carbon accumulation in agricultural soils after afforestation: a meta-analysis. Global Change Biology, 16, 439-453.

Lal R (2004) Soil carbon sequestration to mitigate climate change. Geoderma, 123, $1-22$.

Lal R, Kimble JM (1997) Conservation tillage for carbon sequestration. Nutrient Cycling in Agroecosystems, 49, 243-253.

Larionova AA, Rozaniva LA, Yevdokimov IV et al. (2003) Land-use change and management effects on carbon sequestration in soils of Russia's South Taiga zone. Tellus, 55B, 331-337

Le Quéré C, Raupach MR, Canadell J-G et al. (2009) Trends in the sources and sinks of carbon dioxide. Nature Geoscience, 2, 831-836.

Lepers E, Lambin EF, Janetos AC et al. (2005) A synthesis of information on rapid land-cover change for the period 1981-2000. BioScience, 55 , 115-124.

Lopes de Gerenyu VO, Kurganova IN, Kuzyakov Y (2008) Carbon pools and sequestration in former arable Chernozems depending on restoration period. Ekologiia $54,38-44$.

Lyuri DI, Goryachkin SV, Karavaeva NA et al. (2010) Dynamics of Agricultural Lands of Russia in XX Century and Postagrogenic Restoration of Vegetation and Soils. Geos, Moscow [in Russian].

Macías F, Arbestain MC (2010) Soil carbon sequestration in a changing global environment. Mitigation and Adaption Strategies for Global Change, 15, 511-529.

Mikhailenko BY, Bobkov UK (eds) (1988) Political and administrative map of USSR, Scale 1:8M. Central Administration for Geodesy and Cartography (GUGK), Moscow, Russia [in Russian].

Mikhailova EA, Bryant RB, Vassenev II et al. (2000) Cultivation effects on soil carbon and nitrogen contents at depth in the Russian Chernozem. Soil Science Society of America, 64, 738-745.

Morris SJ, Bohm S, Haile-Mariam S et al. (2007) Evaluation of carbon accrual in afforested agricultural soils. Global Change Biology, 13, 1145-1156.

Nilsson S, Shvidenko A, Stolbovoi V et al. (2000) Full Carbon Account for Russia, Unpublished Interim Report IR-00-021. International Institute for Applied Systems Analysis, Laxenburg, Austria.

Orlov DS (1998) Organic substances of Russian soils. Eurasian Soil Science, 9, 946-953.

Pan Y, Birdsey R, Fang J et al. (2011) A large and persistent carbon sink in the world's forests. Science, 19, 988-993.

Paustian K, Cole CV, Sauerbeck D et al. (1998) $\mathrm{CO}_{2}$ mitigation by agriculture: an overview. Climatic Change, 40, 135-162.

Paustian K, Six J, Elliot ET et al. (2000) Management options for reducing $\mathrm{CO}_{2}$ emissions from agricultural soils. Biogeochemistry, 48, 147-163.

Poeplau C, Don A (2013) Sensitivity of soil organic carbon stock and fractions to different land use change across Europe. Geoderma, 192, 189-201.

Poeplau C, Don A, Vesterdal L et al. (2011) Temporal dynamics of soil organic carbon after land-use change in the temperate zone-carbon response functions as a mode approach. Global Change Biology, 17, 2415-2427.

Post WM, Kwon KC (2000) Soil carbon sequestration and land use change: processes and potential. Global Change Biology, 6, 317-327.

Prishchepov AV, Radeloff VC, Baumann M et al. (2012) Effects of institutional changes on land use: agricultural land abandonment during the transition from state-command to market-driven economies in post-Soviet Eastern Europe. Environmental Research Letters, 7, 024021. doi: 10.1088/1748-9326/7/2/024021.

Prishchepov AV, Müller D, Dubinin M et al. (2013) Determinants of agricultural land abandonment in post-Soviet European Russia. Land Use Policy, 30, 873-884.

Ramankutty N, Delire C, Snyder P (2006) Feedbacks between agriculture and climate: an illustration of the potential unintended consequences of human land use activities. Global and Planetary Change, 54, 79-93. 
Rojkov VA, Wagner VB, Kogut BM et al. (1996) Soil Carbon estimates and Soil carbon map for Russia. Unpublished Working paper WP 96-60. International Institute for Applied Systems Analysis, Laxenburg, Austria.

Romanovskaya AA (2008) Carbon and nitrogen accumulation in abandoned lands of Russia. Lžūu Mokslo Darbai, 80, 82-91. [in Russian].

Russia in figures (2012) Rosstat, Moscow. Available at: http://www.gks.ru/bgd/ regl/b12_12/IssWWW.exe/Stg/d01/15-12.htm (accessed on 4 December 2012).

Russia in figures (2011) Rosstat, Moscow [in Russian]. Available at: http://www.gks. $\mathrm{ru} / \mathrm{bgd} / \mathrm{regl} / \mathrm{b} 11 \_12 /$ Main.htm (accessed on 12 September 2011).

Schlesinger WH (1999) Carbon sequestration in soils. Science, 284, 2095.

Schulze ED, Ciais P, Luyssaert S et al. (2010) The European carbon balance. Part 4: integration of carbon and other trace-gas fluxes. Global Change Biology, 16, 1451-1469.

Silver WL, Osterlag R, Lugo AE (2000) The potential for carbon sequestration through reforestation of abandoned tropical agricultural and pasture lands. Restoration Ecology, 8, 394407.

Six J, Elliott ET, Paustian K et al. (1998) Aggregation and soil organic matter storage in cultivated and native grassland soils. Soil Science Society of America Journal, 62, $1367-1377$

Six J, Conant RT, Paul EA et al. (2002) Stabilization mechanisms of soil organic matter: implications for C-saturation of soil. Plant and Soil, 241, 55-176.

Smith P (2004) Soils as carbon sinks: the global context. Soil Use and Management, 20, 212-218

Smith J, Smith P, Wattenbach M et al. (2005) Projected changes in mineral soil carbon of European croplands and grasslands, 1990-2080. Global Change Biology, 11, 2141 2152.

Smith J, Smith P, Wattenbach M et al. (2007) Projected changes in the organic carbon stocks of cropland mineral soils of European Russia and the Ukraine, 1990-2070. Global Change Biology, 13, 342-356.

Steffen W, Noble I, Canadell J et al. (1998) The terrestrial carbon cycle; implication for the Kyoto protocol. Science, 280, 1393-1394.

Stolbovoy V (2002) Carbon in Russian soils. Climatic Change, 55, 131-156.
Targulyan VO, Gerasimova MI (eds) (2007) Word Reference Base for Soil Resources 2006. KMK Scientific Press Ldt, Moscow [in Russian].

Titlyanova AA, Naumov AV (1995) Carbon losses from soils of Western Siberia under agriculture. Eurasian Soil Science, 11, 1357-1362.

Titlyanova AA, Bulavko GI, Kudryashova SYa et al. (1998) Stocks and losses of organic carbon in soils of Siberia. Eurasian Soil Science, 1, 51-59.

Vuichard N, Ciais P, Belelli Marchesini L et al. (2008) Carbon sequestration due to the abandonment of agriculture in the former USSR since 1990. Global Biogeochemical Cycles, 22, GB4018, doi: 10.1029/2008GB003212.

West TO, Post WM (2002) Soil organic carbon sequestration rates by tillage and crop rotation: a global data analysis. Soil Science Society of America Journal, 66, 1930-1946.

Yanvareva LF (1989) Map of land categories of USSR. Scale 1:4M. Central Administration for Geodesy and Cartography (GUGK), Moscow, Russia, 4 sheets [in Russian].

Zamolodchikov DG, Grabovskii VI, Kraev GN (2011) Twenty years retrospective forest carbon dynamics in Russia. Contemporary Probl Ecol, 4 , 706-715.

\section{Supporting Information}

Additional Supporting Information may be found in the online version of this article:

Table S1. References included in the database for estimation of changes in organic carbon stock in $0-20 \mathrm{~cm}$ after conversion of croplands to natural vegetation in the main soil types of Russian Federation.

Data S1. References. 